\title{
Teologia da missão e violência: Superar a violência interna e agir energicamente contra a injustiça
}

Mission Theology and violence:

Overcoming internal violence and

energetically acting against injustice

\section{Abdruschin Schaeffer Rocha, David Mesquiati de Oliveira*}

Faculdade Unida (UNIDA), Vitória, Espírito Santo, Brasil

\section{Resumo}

O texto apresenta uma reflexão de cunho mais geral sobre a relação entre violência e religião e uma mais específica sobre a teologia da missão a partir da superação da violência na prática missionária. Aponta os principais desafios para superação da violência na missão e sugere que se deva começar pela própria estrutura das igrejas (internamente). Não basta instruir a missão para que seja feita de forma respeitosa, é preciso que as igrejas e a Teologia Prática

*ASR: Doutor em Teologia, e-mail: abdo@faculdadeunida.com.br

DMO: Doutor em Teologia, e-mail: david@faculdadeunida.com.br 
deem exemplo de que é possível se constituir sem estar assentado em conflitos e violência. Aponta a kénosis de Deus em Jesus como percurso necessário para uma Teologia Prática na superação da violência. Jesus mostra outro percurso ao romper com a "Lei do Talião", quebrando a espiral da violência ao reter o desejo de vingança. É evidente que o modo de agir das igrejas deve estar em consonância com o modo de agir apontado por Jesus. É nesse sentido que se fala de uma superação da violência no seguimento de Jesus, mesmo daquela que se expressa na omissão do enfrentamento e que se esconde no véu do pacifismo. 0 texto está dividido em duas partes: na primeira, discute-se a questão da relação entre religião, cultura e violência. Na segunda, o artigo debate como a Teologia Prática, especificamente a missão, pode construir-se a partir da superação da violência.

Palavras-chave: Teologia Prática. Missão cristã. Superação da violência.

\section{Abstract}

The text presents a general reflection on the relationship between violence and religion and a specific reflection on Theology of Mission from overcoming violence in missionary practice. It points out the main challenges to overcoming violence in the Mission and suggests that one should start with the very structure of the churches (internally). It is not enough to instruct the Mission to be done in a respectful way, it is necessary for churches and Practical Theology to be an example of what it is possible to establish without being based on conflicts and violence. The article points to the kénosis of God in Jesus as a necessary path for a Practical Theology from overcoming violence. Jesus shows another way by breaking with the "Law of Talion", breaking the spiral of violence by retaining the desire for revenge. It is evident that the acting way of the Christian churches must be in accordance with the acting way pointed out by Jesus. It is in this sense that we speak of overcoming violence in the following of Jesus, even that, which is expressed in the omission of the confrontation and that hides itself in the veil of pacifism. The text is divided into two parts: the first discusses the relationship between religion, culture and violence. In the second part, the article discusses how Practical Theology, specifically Mission Theology, can be built from the perspective of overcoming violence.

Keywords: Practical Theology. Mission. Overcoming Violence. 


\section{Introdução}

A violência tem sido relacionada diretamente com a religião. A proposta deste artigo é sustentar que não há uma relação de causaefeito entre religião e violência, nem que necessariamente a missão seja um tipo de violência. Ao contrário, sustenta-se que é possível pensar na atividade missionária das igrejas opondo-se energicamente contra as violências, desde que se superem as incoerências institucionaishierárquicas (ação interna) das igrejas cristãs, e haja compromisso profético no seguimento de Jesus na luta contra a injustiça no mundo (ação externa). A argumentação do texto está dividida em duas partes. $\mathrm{Na}$ primeira, discute-se a questão da relação entre religião, cultura e violência e na segunda, o artigo discute como a Teologia Prática, especificamente a Teologia da Missão, pode construir-se a partir da superação da violência.

Nas narrativas bíblicas, a violência aparece de diversas formas. De acordo com Vila e Escuain (1985), a violência seria a expressão da energia e do esforço humano para exercer um domínio ilegítimo sobre o outro, sob influência do pecado. Alfonso Lockward (1999) afirma que na Bíblia o termo violência vem do hebraico hamas e diz respeito a uma força que é exercida de forma maligna contra outra pessoa. Em Gênesis 6,11 se diz que "a violência encheu a terra"; em Jó 35,9 se dá a entender que o ser humano estaria inclinado à violência; o Salmo 10,18 anuncia o juízo divino para cessar essa inclinação; em Eclesiastes 4,1 há um desejo por intervenção divina para fazer cessar a violência. No Novo Testamento, além de Jesus e, especialmente, da seção do Sermão da Montanha, no qual os cristãos são chamados a viver a paz e o amor de Deus, e se necessário "dar a outra face" (Mateus 5,39), há também a recomendação paulina para revestir-se de "humildade" e "mansidão" (Colossenses 3,12).

Na linguagem dos Salmos, os "maus" "amam" a violência $(11,15)$ e confiam nela para enriquecer-se $(62,10)$. A violência é o meio pelo qual a soberba e o ódio são satisfeitos. De acordo com Vila e Escuain (1985), a esperança do cristão é de um futuro sem violência (2Pedro 3,13; Apocalipse 21,3-5) confiando que Cristo superará toda oposição e maldade (1Coríntios 1524-26). Em Mateus 5,5, os mansos são chamados bem-aventurados e convidados a possuir a terra. Contra os impérios 
fundados com violência e soberba, a esperança é de um novo reino liderado pelo "Príncipe da Paz" (Isaías 9,6). Jesus, como esse príncipe, teria rompido com a "Lei do Talião" (Êxodo 21,24), que enfrentava a violência com a própria violência. De acordo com Lohfink (1986), em Mateus 5,38 Jesus mostra outro caminho, quebrando a espiral da violência ao reter o desejo de vingança. É evidente que o modo de agir das igrejas deve estar em consonância com o modo de agir apontado por Jesus, se efetivamente se entendem como suas seguidoras e anunciadoras do evangelho da paz e da justiça. É nesse sentido que falamos em superar a violência no seguimento de Jesus, o Deus que se faz humano, em todos os níveis possíveis.

\section{Religião, violência e cultura}

É relativamente comum a ideia de que a violência é resultado inevitável da religião. Maurice Merleau-Ponty, por exemplo, advogava a ideia de que a violência religiosa é inerente à essência da religião. A relação com o Absoluto, nesse sentido, implicaria na morte de tudo o que se nomeia sob o signo da contingência, incluindo a morte da autonomia humana (SCHILLEBEECKX, 1997, p. 171). Mais recentemente, tal crítica à religião tem sido protagonizada por ateus como, por exemplo, Richard Dawkins, para quem a religião é a causa da violência, das desgraças e do medo do mundo e a fé um vírus mortal que deveria ser extirpado (DAWKINS, 2007) ${ }^{1}$. Percebe-se que embora a crítica, em geral, se concentre mais na dimensão institucional da religião, também inclui o caráter violento de uma suposta relação direta com o Absoluto. Isso

1 É necessário pontuar que toda postura intelectual que atribua à religião todos os males e desserviços prestados à humanidade precisa prestar contas históricas de alguns dos maiores genocídios do século XX, materializados em países onde 0 ateísmo era o regime oficial, tais como a União Soviética de Stalin e a China de Mao Tsé-Tung. Atribui-se ao regime de Mao, por exemplo, cerca de 70 milhões de mortos resultantes do movimento revolucionário (CHANG; HALLIDAY, 2012). Ou seja, o fato de que a religião tenha servido de plataforma para genocídios precisa ser colocada lado a lado com movimentos que ensinavam a não violência, tais como os Quakers e o movimento wesleyano do século XVIII, ou mesmo a luta pelos direitos civis empreendida por Martin Luther King, por um lado, e também com iniciativas de violência em contextos laicos ou ateus, tais como os movimentos revolucionários citados, por outros. 
colocaria a religião diretamente ligada à violência, o que também sugeriria esta como elemento constitutivo daquela.

Mas, seria a religião - seja do ponto-de-vista institucional ou mesmo da experiência epifânica - o lugar por excelência da violência? Estaria a violência implicada no proprium da religião, incluindo, é claro, o cristianismo? Ou a violência deveria ser buscada nas instâncias humanas que precedem o sentido religioso?

\section{Edward Schillebeeckx: religião e ontologia da violência}

Em um artigo publicado em 1997, o teólogo dominicano belga Edward Schillebeeckx defende a ideia de que a violência não se liga à essência da religião. Para tanto, define a religião como a forma cultural de uma salvação-a-partir-de-Deus, considerando o modo como ela nos aparece concretamente (SCHILLEBEECKX, 1997, p. 168). A religião tratada por Schillebeeckx, aqui, é a religião mediatizada, institucionalizada, concretamente expressa na história, e não a religião como experiência selvagem, ou seja, pré-racional, instância fundante de toda instituição religiosa na perspectiva da reflexão filosófica da religião. As pessoas humanas, que também são seres culturais, são os sujeitos da religião.

A cultura concreta modela a fé cristã, medeia a fé que é assimilada na vida e é o lugar dentro do qual essa fé é praticada concretamente pelas pessoas. Nesse sentido, para Schillebeeckx, a mediação sociocultural também pode favorecer uma aproximação entre religião e violência. Como componente sociológico da sociedade cultural, a religião pode ser promotora de violência, já que, de certa forma, encontra-se por este condicionada. O desejo de superioridade, por exemplo - de cujo mal o cristianismo não é uma exceção -, constitui obstáculo ao convívio com outras religiões e ao estabelecimento de uma cultura digna dos seres humanos (SCHILLEBEECKX, 1997, p. 168-169). Nesse sentido, para Schillebeeckx, considerando a realidade histórica na qual se insere a religião, não existiria uma conexão interna entre sua essência (a relação com o absoluto transcendente-imanente) e a violência religiosa, embora na prática seja possível à religião, na medida em que busca sua pretensão 
de verdade, envolver-se com pressupostos estranhos ao que se poderia chamar de essência da religião (1997, p. 170).

O fato surpreendente de muitos grandes teólogos, como, por exemplo, Tomás de Aquino (visto, em certo sentido, como um homem manso) terem legitimado teologicamente a violência, mostra que não se trata de um assunto fácil de discernir, sobretudo, se para essas pessoas a relação com o absoluto é uma questão de vida ou morte. Uma das dificuldades de se avaliar o tema é que essa relação não é dada de maneira frouxa, afinal, para o crente, "nada do que é humano pode subtrair-se a este laço de criação com o Absoluto” (SCHILLEBEECKX, 1997, p. 172). Ainda para o autor, visto a partir de nossa perspectiva, toda "ligação direta” de Deus com os seres humanos é mediada: há, porém, mediações boas e mediações ruins. Com isso, Schillebeeckx obviamente deseja estabelecer a violência como uma mediação ruim. As falsas alianças que se dão a partir de mediações equivocadas podem estimular pessoas a uma violência religiosa, em nome da relação com o Absoluto. É nesse sentido que tal relação, portanto, pode ser libertadora ou ameaçadora para as pessoas. Embora a religião não seja essencialmente má, toda violência em nome da religião é essencialmente má (SCHILLEBEECKX, 1997, p. 172).

O que Schillebeeckx (1997) deseja mostrar é que a violência religiosa possui fundamentos que são falsos, mas esses fundamentos não são necessariamente nem de origem religiosa nem cristã. A pretensão de uma religião de ser a única religião verdadeira - o primeiro fundamento falso, em sua opinião - é uma postura violenta, porquanto nega a legitimidade da existência de outras religiões. Entretanto, sua origem é humana e, como tal, está sujeita a uma hermenêutica da existência, cuja crítica pressupõe que se faça justiça a todos os seres humanos, afinal, a dignidade humana constitui-se na base direta do ethos humano, mesmo que na região dessa autonomia humana sejam encontrados vestígios de transcendência religiosa.

O segundo falso fundamento, na opinião do teólogo dominicano, manifesta-se na suposição equivocada "de que a relação religiosa com o Absoluto implica numa conexão direta com a ordem sócio-política criada pelos homens" (SCHILLEBEECKX, 1997, p. 175). Trata-se de elevar uma determinada moral à condição de "vontade de Deus", atitude provocada 
por uma aliança da religião cristã com o antigo conceito da "religio". Dessa atitude de estabelecer uma conexão direta entre o Absoluto e uma determinada ordem sócio-política terrena, surge a violência, porquanto se constitui num abuso da religião, que pode tanto se manifestar numa religião do Estado como no mero reconhecimento estatal de alguma "religião oficial". Semelhantemente ao primeiro falso fundamento, este também é condenável, enquanto expressão de violência, mas por razões humanas e éticas. Afinal, constitui-se numa violação dos direitos humanos.

Assim como se poderia argumentar que a violência não é inerente à religião, mas pode ser instrumentalizada por ela, o mesmo se dirá de posturas pacifistas, que podem ser fictícias ou instrumentos de manipulação da realidade: toda experiência de libertação é humana, mesmo antes de ser capitaneada pela religião (etsi Deus non daretur) ${ }^{2}$. Tal pressuposto, obviamente, abre as portas para novas perspectivas que se estabelecem a partir de uma visão secularizada, contribuindo para uma religião mais humana — na acepção de Schillebeeckx (1997), uma "profecia de fora", afinal, o mundo secularizado pode ensinar muitas coisas às religiões, sobretudo às igrejas cristãs, na medida em que se constitui numa pressão que se insinua de fora para dentro. Sem dúvida, disso derivam muitas implicações para a prática missionária numa perspectiva de superação da violência.

\section{René Girard: uma antropologia da violência}

Se, de fato, é possível desvincular a violência - tanto quanto o pacifismo - da essência da religião abre-se espaço para pensá-la a partir de instâncias essencialmente humanas, que precedam o sentido religioso, embora a religião encontre lá suas verdadeiras raízes. Para tal empreitada, é de capital importância às contribuições de René Girard, que tem sido

2 Para Schillebeeckx, o sentido religioso é sempre posterior ao sentido humano, razão pela qual falar muito cedo sobre Deus sem o devido lastro humano e histórico pode suscitar um discurso que se estabeleça a partir de uma imagem envelhecida de Deus. Nesse sentido, todo acontecimento que seja libertador dos seres humanos já é humanamente relevante, mesmo que não faça referência direta a Deus (Cf. SCHILLEBEECKX, 1994, p. 24). 
considerado um dos mais importantes pensadores contemporâneos a pensar a violência numa perspectiva antropológica e sua relação com a religião.

Um dos principais conceitos de Girard e que orientou boa parte de sua obra, tem sido conhecido como "teoria do desejo mimético". Girard busca na literatura as fontes para uma compreensão mais ampla do desejo mimético, afinal, para ele, trata-se da disciplina que melhor nos aproximaria das emoções e desejos humanos. Segundo essa teoria, a relação entre o sujeito e o objeto de seu desejo não se dá diretamente, mas de forma triangular, porquanto passa pelo desejo de outro.

A teoria de Girard surge como uma alternativa tanto ao realismo quanto ao idealismo: no realismo alguém amaria porque o objeto desejado é amável, ou seja, possui qualidades que inevitavelmente suscitariam o amor do sujeito; no idealismo alguém amaria o objeto de seu desejo porque tal motivação reside no próprio sujeito e em suas projeções. Em ambas as possibilidades é possível identificar o desejo como algo inerente ao ser humano na perspectiva de uma falta, lugar-comum na maioria das teorias do desejo cuja estruturação é binária ${ }^{3}$.

A teoria de Girard se diferenciaria tanto do realismo quanto do idealismo, na medida em que um determinado sujeito desejaria seu objeto, não porque o objeto é desejável, tão pouco porque a motivação para o desejo provém do sujeito, mas porque o objeto também é desejado por outro. Nesse caso, a relação entre sujeito e objeto é mediatizada por outro sujeito. Renuncia-se, portanto, à primazia tanto do sujeito quanto do objeto para se afirmar a primazia do rival. E é na medida em que os dois desejos convergem para o mesmo objeto e que, portanto, cada desejo é a imitação do outro, que se instala tal rivalidade (GIRARD, 2008, p. 184) ${ }^{4}$. As pessoas são guiadas por um mimetismo instintivo que desencadeia “comportamentos de apropriação mimética”, responsáveis por gerar tais

3 Para Girard, o desejo não é algo inato, não é animal. Além disso, segundo o autor, não sabemos nem mesmo se 0 desejo é intrinsecamente humano, afinal, se em alguns momentos ele parece humano, em outros parece intensamente desumano. Para Girard, o que se pode falar sobre o desejo é que nasce da contemplação de outra pessoa (modelo) que está desejando algo.

4 Para Girard, entretanto, embora o ser humano deseje intensamente - uma vez que os desejos primários já estejam satisfeitos -, ele não sabe exatamente o que deseja. Não é o objeto que, por suas propriedades, suscita o desejo do sujeito, afinal, é fundamental que o outro lhe diga o que é necessário desejar a fim de que 0 sujeito adquira o seu objeto mimeticamente desejado. 
conflitos. Ou seja, esse desejo enquanto drama existencial jogado a três é o que, na opinião de Girard, inaugura e deflagra a violência.

Mas, essa relação mimética, caracterizada pelo conflito entre sujeitos e a violência gerada, traz à tona outro importante elemento na teoria girardiana que é a solução ao conflito instaurado pelo desejo mimético: o mecanismo do bode expiatório, ou seja, a solução coletiva para a perpetuação da sociedade. Instaura-se, portanto, a relação do tipo "todos contra um". Esse contra o qual se insurge a coletividade é um membro da comunidade expulso dela, que nas sociedades tradicionais é considerado tanto a origem da violência quanto a sua solução. Nesse caso, a violência figura como um componente presente nas sociedades humanas que deve ser recorrentemente contido e afastado por meio do sacrifício de vítimas expiatórias. Ou seja, é inevitável que se recorra à violência para liquidá-la, e exatamente por isso que ela é interminável, na acepção de Girard. "A violência é de todos e está em todos”. Para Girard, é desse processo que se origina o sagrado, afinal, a vítima separada da comunidade também é divinizada. O sacrifício é ambivalente, porquanto se apresenta tanto como "algo muito sagrado", quanto como uma espécie de crime. Sacrifício e assassinato, portanto, guardam uma relação de parentesco (GIRARD, 2008, p. 11-12).

Percebe-se, então, que o sacrifício implica na necessidade de aniquilação da vítima. Mas a aniquilação ganha o status de sacrifício na medida em que "engendra algo de sagrado", afinal a expressão deriva dos termos sacrum e facere, que significam "tornar sagrado". Essa ambiguidade ontológica, que deriva da ambiguidade terminológica, mostra que o "ato sacrificial violento gera uma experiência de sacralização" (BASTOS; CABRAL; REZENDE, 2010, p. 152). É exatamente no sacrifício que a violência é sacralizada. A violência, nesse sentido, além de legítima, tornase necessária, afinal, só "é possível ludibriar a violência fornecendo-lhe uma válvula de escape, algo para devorar" (GIRARD, 2008, p. 15).

Mas, deve-se ressaltar que tanto o sagrado surge originariamente do ato de violência, pela aniquilação do bode expiatório, como também a cultura e sociedade, afinal, tem-se que a imolação do bode expiatório é evento fundante na medida em que somente por meio dele uma sociedade é possível - somente quando todos se unem de forma violenta 
contra a vítima, cria-se a comunidade (BASTOS; CABRAL; REZENDE, 2010, p. 165). Embora Girard se mostre reticente quanto a conceber o desejo como constitutivo do ser humano, por outro lado, admite-o como constitutivo da sociabilidade humana. E se considerarmos a sociabilidade como constitutiva do humano - lugar-comum nas antropologias contemporâneas - , então deveríamos admitir, no mínimo, que a gênese da violência deve ser buscada no âmago da existência humana, e não propriamente na essência da religião, sobretudo, quando consideramos que mesmo esta é consequência daquela.

\section{Gianni Vattimo: a superação da violência religiosa}

Tanto René Girard quanto o filósofo italiano Gianni Vattimo assumem uma perspectiva bem particular em relação à famosa declaração de Nietzsche de que "Deus está morto", frase que expõe o niilismo do filósofo alemão. Enquanto para Girard a morte de Deus tem a ver com a morte real de uma vítima inocente, Cristo, em quem se completa a revelação em sentido não vitimário ${ }^{5}$, para Vattimo a morte de Deus como evento possível no âmbito da encarnação se dá na perspectiva de um enfraquecimento de seu poder transcendente.

De modo geral, o pensiero debole (pensamento fraco) ${ }^{6}$ pretende anunciar o fim da aventura metafísica do pensamento. Ou seja, tal formulação pressupõe uma crítica a todo esforço humano em busca de um acesso privilegiado ao ser, portanto, critica a noção de fundamentos imutáveis que afiancam uma verdade absoluta. Para Vattimo, numa retomada do pensamento de Heidegger, nisso consiste a violência: no modo como a metafísica reduz o ser à objetividade e à racionalização,

5 Vale ressaltar que, para Girard, há significativas distinções entre a estrutura dos mitos e os relatos bíblicos, tanto os Evangelhos quanto as Escrituras hebraicas. A principal é que - a despeito das semelhanças estruturais -, diferentemente dos mitos, no caso bíblico a vítima sempre é inocente. 0 cristianismo representa, nesse sentido, a quebra da prática do sacrifício vicário em nossa cultura (GIRARD, 2012, p. 155-218).

6 A expressão pensiero debole tornou-se, para Vattimo, um conceito-chave a partir do qual tem elaborado sua filosofia pós-metafísica, e encontra-se presente explicitamente em várias de suas obras (p.e.: VATTIMO, 1996; VATTIMO, 1990). 
sobretudo no que respeita a existência humana, colocando-o como fundamento último, estável, por assim dizer (GIRARD; VATTIMO, 2010, p. 86). Sua proposta é de um pensamento não metafísico, no qual o ser se mostra como o próprio princípio do enfraquecimento nos seus aspectos dissolutivos: dissolução das instituições políticas que se fundam no autoritarismo; dissolução da confiança num fundamento último que se traduza numa consciência subjetiva; dissolução de todo conceito de realidade, enfim, dissolução do próprio mecanismo vitimário, o que, para ele, se traduz positivamente na própria história da salvação (GIRARD; VATTIMO, 2010, p. 90-91).

Portanto, o enfraquecimento do ser é análogo à dissolução da violência do sagrado, tal qual narrada nas Escrituras judaico-cristãs, na perspectiva de Girard. É nesse sentido que, partindo também das Escrituras, Vattimo propõe o conceito de kénosis como o mais apropriado para associar esses dois pensamentos. Ou seja, a kénosis como a própria encarnação de Cristo no contexto de uma história de salvação, traduz-se numa revelação que se manifesta na progressiva redução da violência original do sagrado e, concomitantemente, na dissolução da reivindicação metafísica da objetividade (GIRARD; VATTIMO, 2010, p. 90-91).

A kénosis, portanto, deve ser interpretada como sinal de um Deus não violento e não absoluto de uma era pós-metafísica. E é nesse sentido que o filósofo torinense propõe o conceito de secularização que, em sua perspectiva, liga-se estreitamente à ideia de dessacralização do sagrado violento, autoritário e absoluto, percebidos na religiosidade natural. Notadamente, trata-se de um sentido positivo para a secularização processo dentro do qual o cristianismo passaria a ser "a religião da saída da religião" (GAUCHET, 1992, p. VIII) —, que não pode ser perdido e que se traduz numa modernidade laica que se constitui como continuação e interpretação dessacralizante da mensagem bíblica. Para Vattimo, portanto, a progressiva dissolução da sacralização naturalista deve ser vista como a própria essência do cristianismo em sua formulação não violenta (VATTIMO, 1996, p. 52-54). 


\section{Por uma Teologia Prática que supere as violências}

As considerações feitas até aqui apontaram para o fato de que nem a violência nem o pacifismo são parte inerente da religião, apesar do elemento religioso ter forte influência sobre os temas da violência e da paz. Apontou-se que a arena principal para enfrentar estas questões não está no campo religioso, senão no antropológico - no humano e no cultural. Esse enfrentamento enérgico das violências no anterior-à-religião pode ser informado pelo elemento religioso, mas também deve estar atento a outras vozes da sociedade. Sendo a Teologia Prática um campo da reflexão teológica que deve estar "permanentemente sintonizada com as necessidades e os anseios do mundo de hoje", uma vez que "reflete criticamente sobre a vida e a ação da Igreja diante dos desafios e das condições sócio-históricas do tempo atual" (HOCH, 2005, p. 33), defende-se aqui que ela se torna Teologia extremamente necessária justamente por estabelecer o diálogo com os demais atores sociais.

A Teologia Prática assume claramente compromisso com o mundo e compromisso com o evangelho: conforme o teólogo luterano Lothar $C$. Hoch, a "Teologia Prática promove o diálogo entre a hierarquia e as bases da Igreja, entre a Igreja e o mundo, entre a teologia e as ciências sociais. Ela é o ponto de intersecção de todas essas grandezas" (HOCH, 2005, p. 34). Mas, justamente porque é um diálogo, não pode haver imposições. É por isso que o caminho para solução da violência apontado foi o da kénosis, emulando o gesto de Deus em Jesus. Nesse sentido, pergunta-se: a Teologia Prática, e mais especificamente a Teologia da Missão, tem trilhado esse caminho ou tem ultrapassado os limites dialogais para impor seus conteúdos e suas preferências? Como o tema da violência é tratado nos manuais de Teologia da Missão? Que percursos seriam indicados para uma Teologia Prática para a superação da violência? Essas são perguntas que buscaremos responder criticamente a partir da Teologia da Missão latino-americana.

\section{A Teologia da Missão protestante e o tema da violência}

Como bem observou o teólogo inglês J. Andrew Kirk (2006), não é comum o tema violência ser tratado nas obras de missão. De fato, ele afirma 
textualmente que "raramente, ou talvez nunca" a questão é mencionada (KIRK, 2006, p. 196). Mesmo na grande obra Missão transformadora, do missiólogo sul-africano David J. Bosch (2009 [1991]), o tema é discutido somente de passagem. Bosch faz menção à violência num trecho da p. 528, mas se apressa em relacioná-la com o marxismo e com a Teologia da Libertação latino-americana:

$\mathrm{O}$ apoio à violência é intrínseco ao marxismo. Sem desculpar a violência do status quo e sua bênção por parte dos cristãos (que constitui, de fato, o problema maior), é preciso expressar preocupação com o apoio à violência revolucionária (que é, em verdade, o problema menor, pois representa efetivamente uma resposta à violência do sistema) que se encontra em algumas ramificações da teologia da libertação (BOSCH, 2009, p. 528).

Ao final da página 528, no entanto, Bosch faz ressalvas indicando que nem todos que defendem um discurso libertário compactuam com a violência, destacando a atuação de Desmond Tutu, Allan Boesak, Martin Luther King e Gandhi (BOSCH, 2009, p. 528). Ao longo das mais de 600 páginas dessa obra que foi considerada pela crítica como magistral, não vemos, no entanto, uma tratativa do tema da violência de forma sistemática. A carreira do autor, no entanto, mostra que ele teve forte envolvimento pela paz na África do Sul, atuando como presidente da Iniciativa Nacional pela Reconciliação a partir de 1989 até sua morte em 1992, aos 62 anos, depois de um acidente automobilístico (cf. ANDERSON, 2009).

Diferentemente da perspectiva de Bosch sobre a teologia latinoamericana, temos a leitura do teólogo luterano brasileiro Roberto Zwetsch (2008), em Missão como compaixão. Este autor destaca uma característica muito positiva da teologia latino-americana, que é a dimensão da alteridade que ela resgatou, uma vez que ela "nasceu como uma caminhada espiritual no meio do povo de Deus" (ZWETSCH, 2008, p. 386). E continua indicando que na base da reflexão teológica latinoamericana estaria "um encontro com Jesus Cristo, que nos interpela de modo particular no rosto do outro". Essa dimensão da alteridade é determinante para a superação da violência: 
Seguir os passos de Jesus na América Latina implica opções concretas em favor da justiça, da liberdade e de uma concepção ativa de luta pela paz. Essas opções, individuais e comunitárias, não são fáceis. Requerem despojamento, conversão e exercício da misericórdia enquanto solidariedade permanente e lúcida, sem os quais o discurso teológico acerca do reinado de Deus corre o risco de se tornar piedade vazia, que compromete o testemunho do evangelho e sua credibilidade (ZWETSCH, 2008, p. 386).

Destaca-se desta citação que "uma concepção ativa de luta pela paz" é essencial, sob o risco de, se não houver engajamento concreto, transformar o discurso sobre o reino de Deus em “piedade vazia”. É Cristo quem está por detrás do rosto em sofrimento do outro. Em Mateus 25, Jesus se apresentou como aquele que teve fome e sede, que esteve preso e com frio. É inquietante perceber que Jesus seria encontrado justamente atrás do rosto do próximo. Em um artigo posterior, o mesmo missiólogo brasileiro debateu explicitamente sobre a luta contra a ditadura brasileira (1964-1985) a partir dos princípios do que ele chamou de não violência ativa, também chamada de firmeza permanente (ZWETSCH, 2014).

As opções concretas em favor da justiça e da paz indicam que a Teologia Prática e a missão em particular necessitam urgentemente de novos parâmetros para a ação. Método, fundamento e conteúdo necessitam ser revisitados uma e outra vez, até que se consolidem novos postulados e práticas humanizadoras e promotoras da vida, em substituição definitiva das antigas perspectivas de missão como conquista e dominação do outro, que embora negadas, existem de forma velada nas pretensões evangelizadoras ${ }^{7}$ de algumas igrejas.

Uma obra a ser destacada é O que é missão? (KIRK, 2006), que diferentemente das outras, dedica um capítulo inteiro à temática da violência (p. 191-215). O missólogo inglês, que conhece bem a realidade latino-americana e teve envolvimento na fundação da Fraternidade Teológica Latino-americana (FTL), afirma que "o evangelismo fica incompleto a menos que aborde o problema da violência e aponte

7 É uma referência aos programas missionários em curso em algumas igrejas evangélicas, por exemplo, que se concentram na prática proselitista, sem atentar para a dimensão mais ampla da missão, como a promoção da paz e da justiça, preocupação ecológica, luta por direitos dos menos favorecidos, entre outros. 
para o sacrifício de Jesus como meio de recuperar a harmonia nos relacionamentos" (KIRK, 2006, p. 193). Andrew Kirk percebe que nas últimas décadas os cristãos estiveram engajados na solução concreta de conflitos em várias regiões do globo, mas que "isso não é geralmente relacionado com o chamado missionário da Igreja" (KIRK, 2006, p. 191). É necessário abordar essas questões desde a teologia da missão: "a superação da violência e a construção da paz é uma parte indispensável da missão cristã” (KIRK, 2006, p. 193).

Em Diálogo e Missão nos Andes (OLIVEIRA, 2016), do teólogo pentecostal brasileiro David Mesquiati de Oliveira, o tema aparece, mas abordado de modo mais específico em relação com os povos indígenas, destacando-se a necessidade urgente de métodos mais dialógicos. Essas obras recentes são exemplos positivos de enfrentamento da questão da violência por parte da Teologia da Missão.

\section{Desafios para uma Teologia Prática na superação da violência}

Não é possível viver sem nenhuma forma de enfrentamento enérgico, quando se deseja levar o evangelho a sério em face da realidade sociocultural. Como vimos, a partir de Schillebeeckx (1997), seja por conta da religião ou, de modo especial, da cultura que sobre ela opera, não há consenso sobre se a maneira de conceber a revelação de Deus, as Escrituras e o senhorio de Jesus não deixaria de ter uma forma autoritária, uma vez que se trata de algo que, em geral, é concebido como estando fora da história, que adentra os assuntos humanos e os governa de forma inconteste. O Estado, por sua vez, para garantir a paz e a ordem, pode utilizar-se do poder de polícia, sendo que, historicamente, este poder foi até mesmo legitimado como de "direito divino".

As narrativas bíblicas apresentam um Jesus que esteve no templo em Jerusalém e observou a exploração que os mercadores exerciam para com os viajantes que vinham ao templo para o sacrifício e dependiam dos produtos ofertados para oferecer sua oferta expiatória. Ele não teria feito críticas à matança de animais e, mais ainda, "não pediu licença" a estes exploradores para atuar. Ao contrário, as narrativas dizem que Jesus 
derrubou as mesas e expulsou os cambistas e os animais que estavam no templo (Mateus 21.12-13); em João 2.15 se diz que ele fez isso usando de um chicote improvisado. Seu protesto não foi silencioso nem do tipo não-ação. Ao contrário, Jesus foi enérgico, tomou posição e foi incisivo. Delimitar o "uso justo" da força e a violência em si não é fácil. Mas, não queremos cair no extremo de dizer que tudo se resolverá na perfeita harmonia e sem conflitos.

Aliás, como afirma Losurdo (2012, p. 132-136), o discurso da não violência pode ser instrumentalizado por grupos que concentram o poder na sociedade, no sentido de inibir as reações individuais ou organizadas do restante da sociedade, especialmente dos que mais sofrem os danos infringidos pelos que manipulam e detêm o poder. Obstar a reação à violência, nesse caso, agrava ainda mais a violência já resignada dos que são continuamente afrontados em sua condição de indignidade humana. Além disso, a não denúncia favorece os grupos que concentram o poder e usurpam os direitos dos demais, perpetrando a violência. Essa nova face da violência, a omissão, é tão destruidora quanto a típica atitude violenta direcionada ao outro pela via da ação. Isto é, a não ação pode conter violência, uma vez que pode se mostrar como descaso para com a injustiça infligida ao outro (falta de denúncia e de interpelação). Assim, temos a violência como ação e como inação. Se a condenação, a interpelação e o confronto contra esses grupos corporativistas podem ser entendidos como violência, na esteira do que pensava Bonhoeffer (2008), é preferível este tipo de violência (ação enérgica dos que se rebelam contra o status quo para buscar justiça e reparação), do que a omissão, uma violência muito maior já que não apenas se abre mão da denúncia e do enfrentamento, mas como um ato de falsa piedade.

Ocorre, porém, que o anúncio profético do evangelho não poderia ser feito de forma violenta, pois o resultado supostamente benéfico das suas intenções missionárias estaria sendo anulado pelo meio violento utilizado, pois no caso do evangelho, o método também é mensagem. A violência presente na prática missionária, em muitos casos, passa de alguma forma por aquilo que Sartre (2009) destacou como sendo o problema com o qual todos precisamos lidar: ao mesmo tempo em que lidamos com a incondicional liberdade do outro — o que significa que não podemos 
controlá-lo plenamente - também dependemos dele e de seu olhar para nos constituir como sujeitos no mundo. E é por essa tensão incontornável que, segundo Sartre, "o inferno são os outros"8 (SARTRE, 1977, p. 98).

Considerando a história do cristianismo e seu caráter de anúncio da mensagem do evangelho, a irredutibilidade do outro sempre foi um problema a ser superado. Afinal, diversas vezes tal anúncio foi levado a efeito projetando-se no outro toda a violência possível que deriva de um discurso "forte", metafísico. Em tais experiências e na maioria das vezes, esse outro teve que ser sacrificado, como destacou Girard (1990) transformando-se numa imagem do si mesmo. Em qualquer projeto cristão de expansionismo, a ameaça do diferente e o medo que este suscita motivam a busca por segurança, estabilidade e certezas. Nessa experiência de confronto, a alteridade é vista como um problema que poderia ser resolvido (violentamente) por meio da religião, e a missão é instrumentalizada para homogeneizar a diversidade com vistas à dominação do outro. Esse tipo de missão, como vimos, passa a ser sinônimo de conquista, de relação assimétrica com o outro - como fruto do desejo por segurança - e de absolutização. A intolerância não suporta a diferença. E como o outro é desconhecido, a diversidade, seja de cor, religião ou gênero, é vista negativamente. A saída equivocada encontrada foi o individualismo. Por isso, a intolerância religiosa nunca está sozinha, mas está relacionada com outras intolerâncias como a racial, de gênero, étnica, de onde vem o racismo, o machismo, a xenofobia, como resultado da dificuldade de lidar com o diferente. Contra isso, a saída para uma Teologia Prática na superação da violência não pode ser o auto enclausuramento (o fechamento comunitário nos guetos religiosos), mas

8 Em sua famosa peça de teatro Huis Clos, conhecida em português como Entre quatro paredes, Jean-Paul Sartre (1977, p. 98), escritor e filósofo francês, registra no momento clímax da peça um diálogo que o tornou célebre. Um dos personagens, Garcin, afirma: “0 bronze... (Apalpa-0). Pois bem! É agora. 0 bronze aí está, eu o contemplo e compreendo que estou no inferno. Digo a vocês que tudo estava previsto. Eles previram que eu haveria de parar em frente desta lareira, tocando com minhas mãos esse bronze, com todos esses olhares sobre mim. Todos esses olhares que me comem. (Volta-se bruscamente). Ah! Vocês são só duas? Pensei que eram muito mais numerosas. (Ri). Então, é isso que é o inferno? Nunca imaginei... Não se lembram? 0 enxofre, a fogueira, a grelha... Que brincadeira! Nada de grelha. 0 inferno... 0 inferno são os outros". Na perspectiva sartriana não há relação humana que não esteja impregnada de tensão. Como o outro também é livre, não 0 podemos controlar, e ao mesmo tempo, precisamos do outro para se conhecer e para agir no mundo.

Rev. Pistis Prax., Teol. Pastor., Curitiba, v. 10, n. 1, 144-166, jan./abr. 2018 
a abertura para o encontro respeitoso com o outro em sua diversidade. Nesse caso, o diálogo aberto e respeitoso será o locus da superação da violência. De modo geral, as igrejas são chamadas ao encontro, à humanização, reconhecendo a dignidade do outro, e isso exige a luta enérgica contra a injustiça (OLIVEIRA, 2016).

A simples observação sobre a forma como grupos cristãos têm feito evangelização nos meios de comunicação de massa, especialmente na TV e rádio, e ultimamente também na internet, mostra que tem sido utilizada linguagem agressiva, depreciativa e intolerante para com os adeptos de outra fé, que não o cristianismo, especialmente em relação às religiões afro-brasileiras, que são demonizadas. É urgente educar para o diálogo não só os pastoralistas, mas também educadores, pais, mães, diferentes líderes religiosos e políticos. Seja pela inércia da tradição com traços misóginos e intolerantes que se sedimentou ao longo dos anos, seja pela ausência de crítica e de discernimento, é urgente refletir sobre a violência presente em nossas relações assimétricas e hierarquizadas, não só na sociedade de modo geral, mas especialmente nas religiões.

Essa tarefa de educar para a superação da violência não deve ser feita isoladamente, como se fosse a meta de um grupo particular. Ao contrário, é importante unir-se a outros grupos e atores sociais para a construção de leis e políticas públicas que criminalizem, fiscalizem e transformem as práticas intolerantes (violentas), e para que se oportunizem melhores condições para convivência pacífica dos seres humanos e dos diferentes grupos religiosos. Na letra da lei está garantida a liberdade de fé e culto, mas ainda vivemos sob um regime autoritário e impositivo da intolerância religiosa (SATHLER-ROSA, 1999). Isso exige cuidados básicos, como atenção à linguagem para que seja inclusiva e respeitosa, o desencorajamento às anedotas pejorativas que envolvem a fé do outro ou sua condição socioeconômica, como exemplos. Do ponto de vista das igrejas, pode-se propor que se organizem mais mesas de encontro que ajudem a superar a ignorância para com o outro e que se avance na construção da paz e da justiça.

Para uma ação efetiva das igrejas na superação da violência, Kirk (2006, p. 205) destaca três questões cruciais: 1) as próprias igrejas têm que ser um exemplo de como resolver conflitos; 2) compreender as causas da 
violência; 3) aprender a aplicar princípios de transformação de conflitos. Esses princípios seriam: a) prevenção de conflitos por meio de mesas de negociação, por meio da educação teológica e da conscientização dos riscos; b) resolução dos conflitos por meio de negociações, cessar-fogo, ajuda emergencial, abrigos para refugiados, entre outros; e c) tratar as consequências, reparação de danos, repatriação de refugiados, punições dos criminosos, restabelecimento da democracia, comissões da verdade, memoriais, perdão, estabelecimento da paz (KIRK, 2006, p. 210).

A atitude e o compromisso da Teologia de Missão de romper com a violência em seus diferentes níveis e extensão abrem um leque de desafios para a prática missionária das igrejas e das pessoas cristãs em geral. A ação missionária deve tratar a questão da superação da violência de forma intencional e sistemática. Já avançamos muito em direção ao encontro entre pessoas de fé diferente, mas ainda falta sedimentar esse caminho de convivência harmônica e respeitosa. A saída do autoenfraquecimento, proposta por Vattimo (1999) poderia ser uma forma de superação da violência na teologia. A partir desse referencial, David Mesquiati de Oliveira (2014, p. 66) afirmou:

[...] na perspectiva do pensamento "fraco", o discurso cristão pode ser uma estória entre outras. Estória essa em que as pessoas acreditam sinceramente e vão para o debate defender sua opinião. Ao fazer essa concessão, inevitavelmente correm-se riscos: desencadear um movimento de relativização da fé cristã, fazendo com que o envio de missionários a outras nações/povos não seja mais parte dos programas missionários da igreja; aprofundar um "sincretismo" religioso, como formas de desgaste do sentido de pertença; e insegurança dos cristãos, por não considerarem sua fé como definitiva e completa. Esses parecem ser os maiores medos de uma prática debole. Abrir mão da absolutização dos conceitos, entretanto, não é o problema, mesmo porque vários deles já mudaram ao longo do tempo, e outros permanecem até hoje com sentidos paralelos (é o caso da salvação, da graça, dos dons espirituais, entre outros). Não se trata de substituir um conceito forte por outro melhor, mas de considerar interpretações possíveis, inclusive a do outro.

Uma missão que se assuma em vulnerabilidade e aberta ao diálogo pode ser mais transformadora e pacifista que o tradicional modelo missionário vigente em muitas igrejas. Por meio da kénosis (Filipenses 2,5-11), Jesus entrou 
na história e assumiu a condição humana na existência da vida mundana. Sofreu as limitações do tempo e do espaço, e por meio dessa ação frágil, aumentou seu potencial de conectar-se com o mundo para o qual se sentiu enviado. Para a missão e para as igrejas há, aqui, um longo caminho a percorrer.

\section{Considerações finais}

A saída para uma Teologia da Missão, e destarte, para a Teologia Prática em chave de superação da violência é enxergar as próprias limitações e construir-se em fragilidade, destituindo-se dos discursos fortes, pretensamente identificados com uma verdade superior (de recorte autoritário) a que só um grupo privilegiado teria acesso. No movimento da kénosis de Deus houve a superação da dicotomia humano-divino, sendo o humano tratado como teologal e com dignidade. Aqui, se abriu espaço para que a missão adquira uma face mais humana e humanizadora do que uma atividade meramente religiosa. Nesse sentido, a superação da violência interna das estruturas institucionais e eclesiásticas que se mostram auto referenciadas em direção a modelos mais democráticos e participativos, e a superação do modelo tradicional missionário centrado no anúncio desencarnado (preocupado com "almas" e não com o ser humano em sua integralidade), para avançar em direção a uma missão que seja capaz de lutar energicamente contra a injustiça no mundo de forma concreta, tornam-se exigências do seguimento do evangelho e do Deus de Jesus Cristo.

Para isso, a missão precisa desenvolver-se em outras áreas, como a capacidade de servir à humanidade (engajar-se e dedicar-se a causas justas, além de assumir responsabilidades na mediação de solução de conflitos), de interpelar estruturas de poder (desafiar e denunciar as estruturas injustas e enfrentar/resistir aos violentos), de partilhar (solidariedade, confiança, acolhida, reciprocidade), de diálogo (comunicar-se, encontrar-se, criar comunhão), entre outros. Essa ampliação da missão dará mais visão para as questões ecológicas, econômicas, sociais, em um mundo que é o centro da ação de Deus e possibilitará às igrejas uma inserção no mundo, semelhante à forma kenótica (vulnerável) da inserção de Jesus na história. 
O caminho da superação da violência é o caminho da reconciliação e da paz. Nesse aspecto, a teologia tem um papel fundamental, sendo ela, também, uma teologia que se construa por negociação e por consensos. A democracia se apresenta aqui como uma não violência institucionalizada, pois o funcionamento se dará por meios pacíficos, sendo o compromisso em buscar a paz em contextos de conflito reais ou iminentes sua guia. A paz, à luz das narrativas bíblicas, tem um caráter integrador, pois demanda justiça, reconciliação e reparação. A paz é ao mesmo tempo uma vivência comunitária e uma experiência existencial.

Por último, o diálogo respeitoso, que prese pela superação da violência, vai se conectar ao máximo com o outro pela via da compaixão e da solidariedade, enfim, por aquilo que é verdadeiramente humano. Ao mesmo tempo, ele não pode ser inibido em sua ação profética e partidária da justiça. Nesse sentido, há limites para a concessão ao outro e para o que se pode tolerar. Sem parâmetros definidos, o diálogo vira desamor, pois dialogar significa que ambas as partes devem estar abertas para ouvir e para internalizar as críticas. O diálogo verdadeiro gera desinstalação, afetação e compromisso. Se os seres humanos estiverem presos em sua autonomia e autocentração, não serão capazes de criar compromissos uns com os outros e de lutar pelo bem comum.

A missão no seguimento de Jesus pode ser um fermento em meio a uma sociedade dominada pela violência, competição e desejos desenfreados. Ao seguir Jesus em sua opção de identificação radical com o mundo, dignificando o humano e unindo-o de forma definitiva e redentora com o divino, a missão cristã estará promovendo a vinculação fraternosororal entre os humanos e dando sua contribuição para a construção da paz em suas realidades múltiplas (espiritual, social, impessoal, internacional, ecológica), superando a violência e realizando a justiça.

\section{Referências}

A BÍBLIA SAGRADA. Trad. João Ferreira de Almeida. ed. rev. e atual. São Paulo: SBB, 1997. 
ANDERSON, G. H. In Memoriam. In: BOSCH, D. Missão transformadora. 3. ed. São Leopoldo: Sinodal, 2009.

BASTOS, A.; CABRAL, A. M.; REZENDE, J. Ontologia da violência: o enigma da crueldade. Rio de Janeiro: Mauad X, 2010.

BOSCH, D. J. Missão transformadora. 3. ed. São Leopoldo: Sinodal, 2009.

BONHOEFFER, D. Discipulado. 10. ed. rev. São Leopoldo: Sinodal; EST, 2008.

CHANG, J.; HALLIDAY, J. Mao: a história desconhecida. 2. ed. São Paulo: Cia das Letras, 2012.

DAWKINS, R. Deus, um delírio. São Paulo: Cia das Letras, 2007.

GAUCHET, M. Il disincanto del mondo: uma storia politica dela religione.Turim: Einaudi, 1992.

GIRARD, R. A violência e o sagrado. 3. ed. São Paulo: Paz e Terra, 2008.

GIRARD, R. Eu via Satanás cair como um relâmpago. São Paulo: Paz e Terra, 2012.

GIRARD, R.; VATTIMO, G. Cristianismo e relativismo: verdade ou fé frágil? Aparecida: Santuário, 2010.

HOCH, L. C. O lugar da teologia prática como disciplina teológica. In: SCHNEIDER-HARPPRECHT, C. (Org.). Teologia prática no contexto da América Latina. 2. ed. São Leopoldo: Sinodal; Aste, 2005. p. 21-35.

KIRK, J. A. O que é missão? Teologia bíblica de missão. Londrina: Descoberta, 2006.

LOCKWARD, A. Nuevo diccionario de la Bíblia. Miami, Fl: Unilit, 1999.

LOHFINK, G. Como Jesus queria as comunidades? A dimensão social da fé cristã. São Paulo: Paulinas, 1986.

LOSURDO, D. A não violência: uma história fora do mito. Rio de Janeiro: Revan, 2012.

OLIVEIRA, D. M. Diálogo e missão nos Andes. São Paulo: Garimpo Editorial; Rio de Janeiro: PUC-Rio, 2016. 
OLIVEIRA, D. M. Missão, cultura e transformação: desafios para a prática missionária comunicativa. 2. ed. São Leopoldo: Sinodal; Quito-Equador: CLAI, 2014.

SARTRE, J-P. Entre quatro paredes. São Paulo: Abril Cultural, 1977.

SARTRE, J-P. O ser e o nada: ensaio de ontologia fenomenológica. 17. ed. Petrópolis: Vozes, 2009.

SATHLER-ROSA, R. A questão da violência: uma aproximação na perspectiva da teologia prática. In: SATHLER-ROSA, R. (Org.). Culturas e cristianismo. São Paulo: Loyola; São Bernardo Campo: Umesp, 1999, p. 57-68.

SCHILLEBEECKX, E. História humana: revelação de Deus. São Paulo: Paulus, 1994. SCHILLEBEECKX, E. Religião e violência. Concilium, Petrópolis, v. 272, n. 4, p. 168-185, 1997.

VATTIMO, G. Creer que se cree. Buenos Aires: Paidós, 1996.

VATTIMO, G. La sociedade transparente. Barcelona: Paidós Ibérica, 1990.

VATTIMO, G. Para além da interpretação: o significado da hermenêutica para a filosofia. Rio de Janeiro: Tempo Brasileiro, 1999.

VILA, S.; ESCUAIN, S. Nuevo diccionario bíblico ilustrado. Barcelona: Clie, 1985.

ZWETSCH, R. E. Missão como com-paixão: por uma teologia da missão em perspectiva latino-americana. São Leopoldo-RS: Sinodal; Quito: Clai, 2008.

ZWETSCH, R. E. A luta contra a ditadura civil-militar a partir da prática da não-violência ativa. Interações - Cultura e Comunidade, Belo Horizonte, v. 9 n. 15, p. 7-28, jan./jun. 2014.

Recebido: 17/07/2017

Received: 07/17/2017

Aprovado: 16/11/2017

Approved: 11/16/2017 